\title{
COMMISSION MANAGER GOVERNMENT IN SAN JOSE, CAL.
}

\author{
BY PROFESSOR ROBERT C. BROOKS \\ Swarthmore College
}

$\mathrm{T}^{\mathrm{B}}$ HERE is no more beautiful or fruitful valley in the world than the Santa Clara in California, and San José is its principal city. The prosperity of the valley is reflected in the growth of the city, which increased in population from 21,500 in 1900 to 28,946 in 1910 . At present it claims, not without large apparent justification, some 40,000 people.

In addition to the superb natural advantages for which it has long been famous, San José recently drew attention to itself by becoming the first city in the state of California to adopt the orthodox commission manager plan. " Its former government was also "orthodox" enough according to the old style, that is with powers and responsibility bewilderingly diffused among various boards, commissions and single officers. The new charter which went into effect July 1, 1916, provides for a council of seven members, all of whom are ultimately to be elected at large for terms of six years. A city auditor and police judge are also chosen by popular vote for terms of four years each. The council selects the city manager and the following other appointive officers: a city clerk, a civil service commission, and a city planning commission. All other appointive officers are appointed and removed by the city manager. The charter also provides for the initiative and referendum, and for the recall of elective officers, the latter action requiring as its first step a petition signed by 25 per cent of the total number voting at the general municipal election next preceding.

As city manager under the new charter, Thomas H. Reed of Berkeley was chosen. At the time of his appointment, Mr. Reed was associate professor in the department of political science at the University of California, and since his graduation from Harvard had won for himself wide recognition as an authority upon municipal government. For a time he served as executive secretary to Governor Hiram W. Johnson. Mr. Reed had been of material assistance to the board of fifteen freeholders who drafted the new charter for San José. He entered upon his office, therefore, well trained in both scientific and practical politics, and thoroughly familiar with the terms of the new instrument.

1 "City Manager Plan," by Joseph H. Quire, Bulletin University Extension Division. University of California, vol. i, no. 18 . June, 1916. 
It is, of course, too early to express a definitive opinion on the workings of the new charter. There lies before the present writer, however, a brief "Report of Progress, July 1 to November 30, 1916," prepared at the end of the old fiscal year by city manager Reed. It is one of the most interesting municipal documents recently issued by any American city, first because of the considerable number of problems which it reports as already solved, and second, because of the new problems indicated for future solution.

Limitations of space forbid more than the briefest mention of the more important items in this record of achievement. The new city manager lost no time in announcing that his office was to be regarded as a bureau of complaints open at all times to all citizens. Purchases were centralized and a system installed whereby it became possible to tell at any moment the exact condition of any city fund. A functional segregated budget was drawn up. As a result some noteworthy savings in purchases were made possible.

An official of one of the leading banks of the city was appointed city treasurer to serve without salary. The funds of the municipality were thereupon transferred from an old ramshackle vault in city hall where they were a constant source of anxiety, to the vaults of the bank which agreed to pay interest at the rate of 2.52 per cent on average daily balances. As a result of this one transaction a saving of $\$ 1,560$ on salaries was effected, to which may be added approximately $\$ 3,000$ a year new income from interest, making a total gain of $\$ 4,560$ annually.

Prior to the first primary occurring under the new régime, the personnel of the city administration was withdrawn from the field of local politics by a "non-participation-in-politics" order issued by the city manager's office. Some compliance on the part of public service corporations with their paving obligations was secured. An ordinance was prepared providing for the co-ordination of the numerous charitable activities of the city, and establishing an effective check upon the solicitation of funds for unworthy objects or for organizations with wasteful methods. An appropriation was made by the council for the codification of the ordinances of the city. Recent appointments to the board of education, the civil service commission, and the board of health have been followed by most gratifying new activities in all three of these fields. A separate and distinct department of electricity was created.

Largely because of the interest taken in the new form of government, San José has been able to secure without payment much valuable technical advice and assistance. Most of this service was rendered by experts from Stanford University and the University of California. One novel contribution of this sort was made by Professor Terman of the department of education of the former institution who employed the Binet and other intelligence tests in a civil service examination for the police and fire departments. 
In Alum Rock park, San José possesses one of the most remarkable scenic reservations adjacent to any American city. It is located in a wild and beautiful cañon seven miles out, but is readily accessible by trolley and excellent roads. All the equipment in this park has been improved, special attention being given to the safety of bathers in the splendid plunge which the city owns. Rentals on concessions were increased about 40 per cent, representing an addition of about four hundred dollars a year to the city's revenue.

Considering the extreme salubrity of San Jose's location and climate, it comes with something of a shock to learn that its death rate has been "as high as the average for the whole registration area of the United States, which includes good and bad communities alike." The new administration, and particularly the new health officers, recognize in this condition one of the gravest problems confronting the city. Already they have to their credit the prevention of two threatening outbreaks of diphtheria. A new laboratory has been fitted up for the work of the health department. Other of its achievements are increased success in securing abatement of nuisances, the institution of a system of standard dairy score cards, and the inspection of tenement and lodging houses. The council has adopted a revised meat inspection ordinance.

For the police department provision has been made in the budget for the purchase of new Bertillon equipment, also for a finger print file. The Boston property file is also being introduced. A police school of instruction is to be started. An adequate supply of ammunition for revolver practice has been provided for in the new budget.

California cities do not grow many stories high up into the air. On the other hand, they do spread in leisurely fashion over ample areas. To enable patrolmen to cover the great beats assigned them in San José, three Fords have been purchased and six new flashlights installed.

With the fire department out of politics the loss from conflagrations has been materially reduced. Ten full-time men were added to the service and other reforms made by which it is hoped that the city may be able to secure from the underwriters' association the lowest key rate for insurance.

A new city engineer has been chosen to direct the important department of public works. Large problems have been marked out for solution in this field, including the control of Coyote creek, sewage disposal, paving, and street cleaning.

In spite of this stirring record of five months' work, - perhaps it would be nearer the truth to say because of it,- -some opposition has developed recently to city manager Reed. It appears to be engineered by a small clique of old line officeholders who were dismissed after their inability to measure up to the new requirements had become manifest. Quite naturally this opposition takes the form of an appeal to a perverted local 
patriotism, a sort of municipal know-nothingism. A small number of appointments of men not at the time living within the immediate limits of the city furnished occasion for the cry: "San Jose for San Joseans." City manager Reed's reply would seem to establish clearly the pettiness of this attack. "Out of seven heads of departments selected by the manager," he writes, "but one is not a San José man. The only other outsider is the manager's personal assistant. . . . Out of 208 permanent positions in the classified service there are only three filled by technical non-residents. Even these are not genuine outsiders, for it is hardly to be said that persons living in the country adjacent to San Jose, who have been educated in our schools and employed by our citizens, are outsiders."

Another ground of attack is the rather vague insinuation of corporate influence over the new administration. The absurdity of this charge is evident to all who will take the trouble to study the record of the new city manager. The alleged impracticability of college professors is also being worked overtime, although in the present instance it is quite clear that the extreme practicality of Mr. Reed is alone responsible for the attacks upon him.

No doubt San José did make something of an innovation in choosing its new executive from the academic career. Hitherto men trained in engineering have been preferred generally for such positions. In smaller cities where the revenue is not sufficient to justify good salaries both for a manager and a city engineer no doubt this course is justified. In cities with larger revenues it is doubtful whether men of engineering training largely should be chosen as city managers. Engineering talent can always be secured, but broadminded executive ability is a much rarer quality needing cultivation in a somewhat more liberal environment. Walter Lippmann is undoubtedly right in maintaining that the statesman,- -and this is as true in the municipality as in the nation,-- "need not be a specialist himself, if only he is expert in choosing experts. It is better indeed that he should have a lay, and not a professional view. For the bogs of technical stupidity and empty formalism are always near and always dangerous."

The case of Progress versus Reaction is now up to San José. It cannot be summed up better than in the words of city manager Reed himself:

We stand to-day in a spirit of deep humility before the solemn responsibilities of the future. The force of traditional habits of thought on government and politics must be overcome. The municipal machine must be speeded up to secure substantial public improvements without increase of expenditure before success is assured. There is no more necessary, no more noble piece of work for real men left in our country. Other cities are hopefully watching our efforts. If we fail we set back not only San José, but every other city struggling toward light. If we succeed, it will only be by a strong united effort of council, manager and people, moving together in harmony and confidence. 